\title{
Some Characteristics and Impacts of the Drought and Water Crisis in Southeastern Brazil during 2014 and 2015
}

\author{
Carlos A. Nobre'1, Jose A. Marengo², Marcelo E. Seluchi², L. Adriana Cuartas ${ }^{2}$, \\ Lincoln M. Alves ${ }^{3}$ \\ ${ }^{1}$ Coordenação de Aperfeiçoamento de Pessoal de Nível Superior (CAPES), Ministério da Educação, Brasilia, \\ Brasil \\ ${ }^{2}$ Centro Nacional de Monitoramento e Alertas aos Desastres Naturais (CEMADEN), São Jose dos Campos, Sao \\ Paulo, Brazil \\ ${ }^{3}$ Centro de Ciência do Sistema Terrestre/Instituto Nacional de Pesquisas Espaciais (CCST/INPE), São Jose dos \\ Campos, São Paulo, Brazil \\ Email: pr@capes.gov.br, jose.marengo@cemaden.gov.br, marcelo.seluchi@cemaden.gov.br, \\ adriana.cuartas@cemaden.gov.br, lincoln.alves@inpe.br
}

Received 25 November 2015; accepted 22 February 2016; published 25 February 2016

Copyright (C) 2016 by authors and Scientific Research Publishing Inc.

This work is licensed under the Creative Commons Attribution International License (CC BY). http://creativecommons.org/licenses/by/4.0/

(c) (i) Open Access

\begin{abstract}
Since the austral summer of 2014 southeastern Brazil has been experiencing one of the most severe droughts in decades. This rainfall deficiency has generated water shortages and a water crisis that have affected population and local economies in the metropolitan region of Sao Paulo, the largest megacity in South America. By January 2015, main reservoirs had reached storage levels of only $5 \%$ of their 1.3 billion $\mathrm{m}^{3}$ capacity. The meteorological causes of the drought situation were linked to changes in the regional circulation, characterized by a mid-troposphere blocking high that lasted 45 days during the summer of 2014 over southeastern Brazil, something not seen in five decades. The water crisis was aggravated by a combination of lack of rainfall and higher temperatures, the summer of 2014 being the warmest and driest over the Cantareira reservoir system since 1951. Increasing population and water consumption increased vulnerability in the region, and while human-induced warming may not have generated the atmospheric conditions behind the 2014 and 2015 summer droughts in Southeast Brazil, it is more likely that the warm temperatures have affected the severity of the drought and exacerbated the impacts on the population.
\end{abstract}

\section{Keywords}

Drought, Sao Paulo, Water Crisis, Vulnerability

How to cite this paper: Nobre, C.A., Marengo, J.A., Seluchi, M.E., Cuartas, L.A. and Alves, L.M. (2016) Some Characteristics and Impacts of the Drought and Water Crisis in Southeastern Brazil during 2014 and 2015. Journal of Water Resource and Protection, 8, 252-262. http://dx.doi.org/10.4236/jwarp.2016.82022 


\section{Introduction}

Hydrometeorological and climate extremes and change can exert profound stresses on urban environments. Since the end of 2013, southeastern Brazil has been struggling through the worst drought in 55 years, and this situation has continued during 2015. Cities such as São Paulo, Rio de Janeiro and Belo Horizonte are facing water shortages, putting a total of 40 million people at risk in the region. Reservoirs that supply water to these cities were at dangerously low levels in 2013/14 and continued very low during 2014/15, due to a deficient rainy season accompanied by record high temperatures and subsequent increase in water demand by the population. We refer to this situation as a "water crisis". Geographically, Southeastern Brazil includes the states of Minas Gerais, Sao Paulo, Espirito Santo and Rio de Janeiro, in the region between $15^{\circ} \mathrm{S}-25^{\circ} \mathrm{S}$ and $40^{\circ} \mathrm{W}$ and $55^{\circ} \mathrm{W}$. The Cantareira Reservoir system is located in the eastern side of the State of Sao Paulo (Figure 1).

Drought and higher temperatures throughout the region were detected, including in the area of the Cantareira Reservoir system, the main supplier of water for the São Paulo Metropolitan Area (SPMA), which continuously provides water to almost 8.8 million in habitants. The state government did not declare an emergency until August $19^{\text {th }} 2015$ when the Alto Tiete reservoir system, the second largest system supplying water for the SPMA, also entered into a crisis situation. The rivers feeding the Cantareira system were very low in 2014 and continue dangerously low in 2015. In the last 60 years, other seasonal droughts have affected the SPMA and southeastern Brazil, such as in 1953/54, 1962/63 [1] and 2000/01 [2], but this current water crisis seems to be the worst both in terms of impacts and in the number of people affected. The SPMA is South America's largest metropolis, where $10 \%$ of Brazilians live (20 million people) and a third of gross domestic product is produced.

In this study we investigate the consequences and impacts of the 2013/14 and 2014/15 drought and related water crisis in Sao Paulo, and assess how extreme these droughts were as compared to other events in the past. We assess some climatic characteristics of the drought situation during the summers of 2013/14 and 2014/15 over the Cantareira reservoir system, and assess the regional hydrology and situation of the reservoirs in the region that characterize the water crisis in 2014 and 2015. The large-scale and regional circulation and SST anomalies in the Pacific and Atlantic Oceans leading to these droughts have been discussed elsewhere [3]-[6].

\section{Data and Methodology}

The main rainfall data set comes from the Brazilian Center for Weather Forecast and Climate Studies of the National Institute for Space Research (CPTEC/INPE) for 1961-2015. For the analysis of the Cantareira reservoir watershed region, station rainfall data comes from National Institute for Meteorology (INMET) for 1961-2015 and the National Center for Monitoring and Early Warning for Natural Disasters (CEMADEN) for 2014 and 2015. Other rainfall data sources are the combination of Tropical Rainfall Measuring Mission (TRMM [7]) satellite precipitation estimates with surface observations over the relevant area $\left(20^{\circ} \mathrm{S}-24^{\circ} \mathrm{S} ; 50^{\circ} \mathrm{W}-46^{\circ} \mathrm{W}\right)$, during the austral summer rainy season-December-January-February DJF of 1961-2015. When needed, interpolation was made using kriging, with the rainfall time series coming from the various data sets. Discharge data sets came from the Sao Paulo State Water Utility Company (SABESP). Data on population for the city of Sao Paulo came from the Municipality of Sao Paulo. Circulation features were derived from the NCEP NCAR reanalises. The Brazilian Institute of Meteorology INMET made available maximum temperature data for the region.

In order to assess drought and precipitation deficits, we use the Standardized Precipitation Index (SPI) on scales of 1, 3, 4, 6 and 12 months to analyze the frequencies of extreme drought (when SPI value $<-2.0$ ) based on the historic rainfall data. The SPI is a tool which was developed primarily for defining and monitoring drought. It allows ananalyst to determine therarityof a drought at a given time scale (temporal resolution) of in terest for any rainfall station with historic data. It can also be used to determine periods of anomalously wet events. The SPI was done at a monthly time scale and the computation was carried out based on gamma distribution function. By transforming the rainfall data into log normal values, the parameters of the gamma distribution were calculated using maximum likelihood estimation. The resulting parameters were then used to find the incomplete gamma cumulative probability of an observed precipitation event. The incomplete gamma cumulative probability was then converted to gamma probabilities after including the occurrences of zero precipitation events. The gamma probabilities were transformed into standardized normal distribution using equi-probability transformation techniques. In other words, the SPI is simply the difference of precipitation from the mean for a specified time period divided by the standard deviation where the mean and standard deviation are determined from past record.

The SPI may be computed with different periods ranging from one month (short-term conditions) to 12 months 


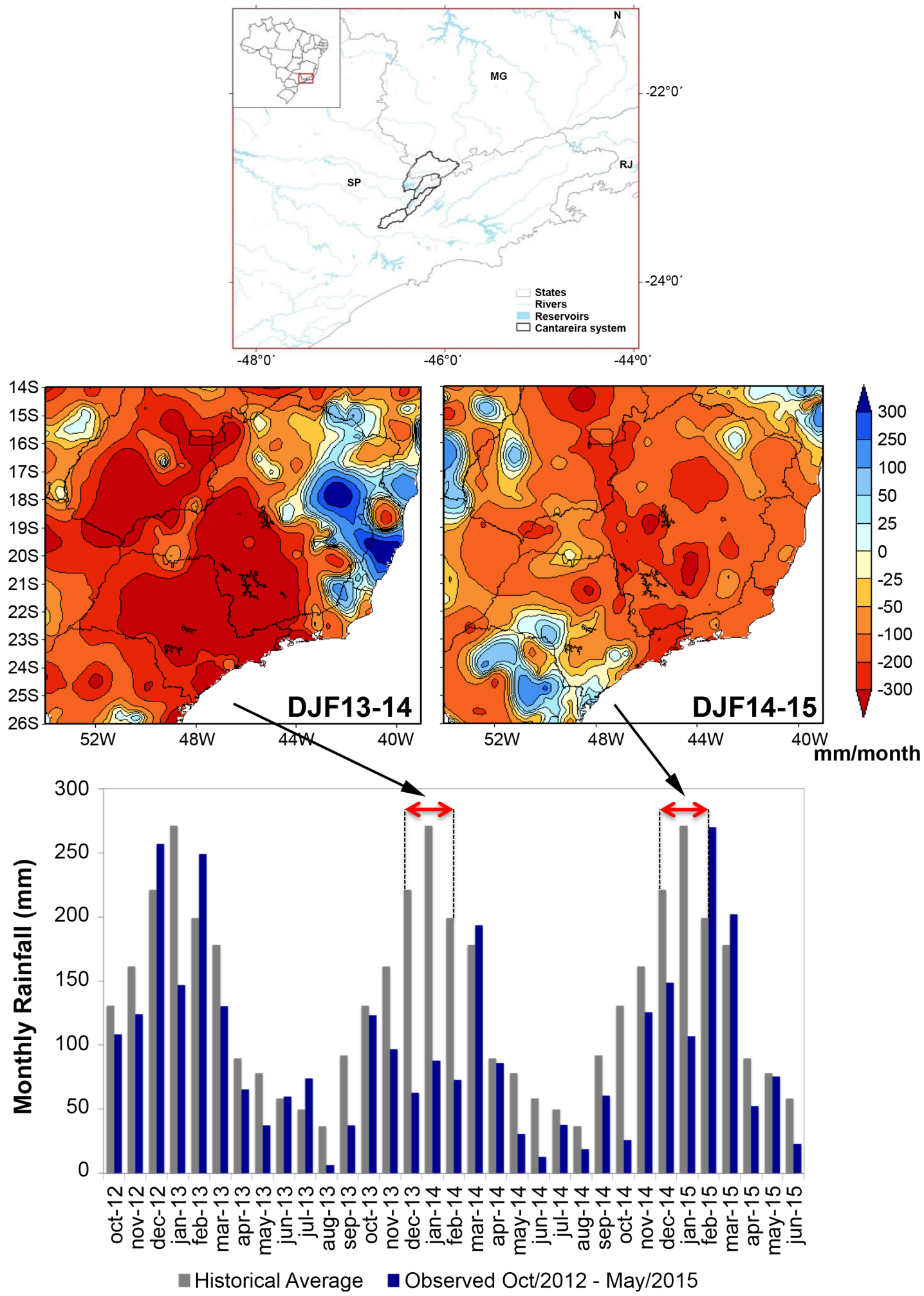

Figure 1. Rainfall time series from October 2012 to June 2015 for the Cantareira region (lower panel). The upper panel maps show the austral summer DJF 2013/14 and 2014/15 rainfall anomalies (mm) in southeastern Brazil, relative to the 1961-1990 climatology. (Source of data: CPTEC/INPE, INMET, ANA, CEPAGRI, CEMADEN.) The map of the state of Sao Paulo (SP) in between the rainfall anomaly maps shows the location of the Cantareira region in red. The map of Brazil in the lower left side of the panel shows the Southeastern Brazil region. 
(long-term conditions). When taken together, they give a temporal picture of the severity of precipitation anomalies and facilitate the assessment of the effects of a precipitation deficit on different water resources components (groundwater, reservoir storage, soil moisture, streamflow). Drought periods are represented by relatively high negative deviations.

\section{Meteorological Context: A Review}

\subsection{Climatological Situation in 2014 and 2015}

The rainy season over Southeast Brazil starts in October and ends in April [8]. November 2013 was a rather normal month in terms of overall rainfall amounts, although some spatial and temporal variability was apparent. During mid- to late December 2013, an intense and persistent South Atlantic Convergence Zone (SACZ) episode affected the states of Minas Gerais and Espírito Santo [9]. The SACZ was linked to an enhanced low-level moisture convergence and rising motion causing intense rainfall and severe flooding and damage. While extreme rainfall affected these states in the northern portion of southeastern Brazil, compensating subsidence induced scarce precipitation and high temperatures over the southern portion (including São Paulo, Rio de Janeiro and southern Minas Gerais).

After the SACZ dissipation in late December 2013, precipitation remained persistently reduced over most of central and southeastern Brazil. Over the Cantareira region, from December 2013 to February 2014 precipitation was about 60\% - 70\% below normal, and 2014/15 rainfall was also below normal (about 25\%) from December 2014 to February 2015 (Figure 1).

Figure 1 shows that mean precipitation for the period from December 2013 to February 2014 in central and southeastern Brazil was about $300 \mathrm{~mm}$ below normal. This tendency still persisted during the summer of 2015 (December 2014-February 2015) but in lesser degree, since while December 2014 and January 2015 showed rainfall below normal, February rainfall was above normal. In both seasons, the region with large negative rainfall anomalies includes the Cantareira reservoir system. Figure 2(a) shows a decreasing trend in precipitation over the Cantareira region since the 1990's, and 2014 shows the lowest rainfall value since 1962. The MannKendall test was applied to the time series of summertime maximum temperature and rainfall in the region of study. The rainfall time series shows a negative trend, significant at the 0.05 level over the period 1994-2015 (and significant at the 0.1 level for the period 1962-2015). On the other hand, daily maximum air temperatures during these summers have increased in time, and maximum temperatures series show positive trends significant at the 0.01 level. Figure 2(b) shows that with less rainfall we have a reduced summertime discharge into the Cantareira system, and higher air temperatures induce an increase in water use exacerbated by the increase in population in the SPMA to 20 million people in 2014, as compared to 17 million in 2001 and 5 million in 1963. The negative rainfall trend detected over the Cantareira since the 1990's seem to be related to changes in rainfall variability over that region, as shown in [8].

Data derived from the Gravimetry Recovery and Climate Experiment (GRACE) mission [10] are used to define the beginning of the current drought over Southeastern Brazil from 2011 to 2015. By using Global Land Data Assimilation System (GLDAS) outputs, it was found that the extreme drought is mostly related to lowerthan-usual precipitation rates, resulting in high soil moisture depletion and lower-than-usual rates of evapotranspiration that started in 2011. A reduction of $20 \%-23 \%$ of precipitation over an extended period of three years is enough to createserious water scarcity conditions in southeastern Brazil.

The regional-scale circulation characteristics associated with the summertime drought of 2013/14 and 2014/ 15 showed that an important characteristic for the 2013/14 droughts was the persistence of a mid-atmosphere blocking high over southeast Brazil. The regional circulation features a wide, intense and very persistent high-pressure area with a barotropic structure over southeast Brazil. Figures 3(a)-(c) show the geopotential height contours and their corresponding anomalies at the 500-hPa level for three different periods: 01-15 January 16-31 January and 01-15 February 2014. It is remarkable that the positive geopotential height anomalies remained almost unchanged for 45 days, something that has no precedent in the region since 1961. Subsidence prevailed in the middle and lower troposphere over southeastern Brazil and subjacent Atlantic Ocean inhibiting distinctive seasonal convective activity. At lower levels, the anomalous anticyclone modified the typical northeasterly flow that brings humidity from the Amazon to Southeastern Brazil. Instead, an there was intense northerly low level moisture transport during several episodes of formation of a low-level jet east of the Andes during the summer of 2014, inducing intense precipitation over western Amazonia that resulted in severe flooding 

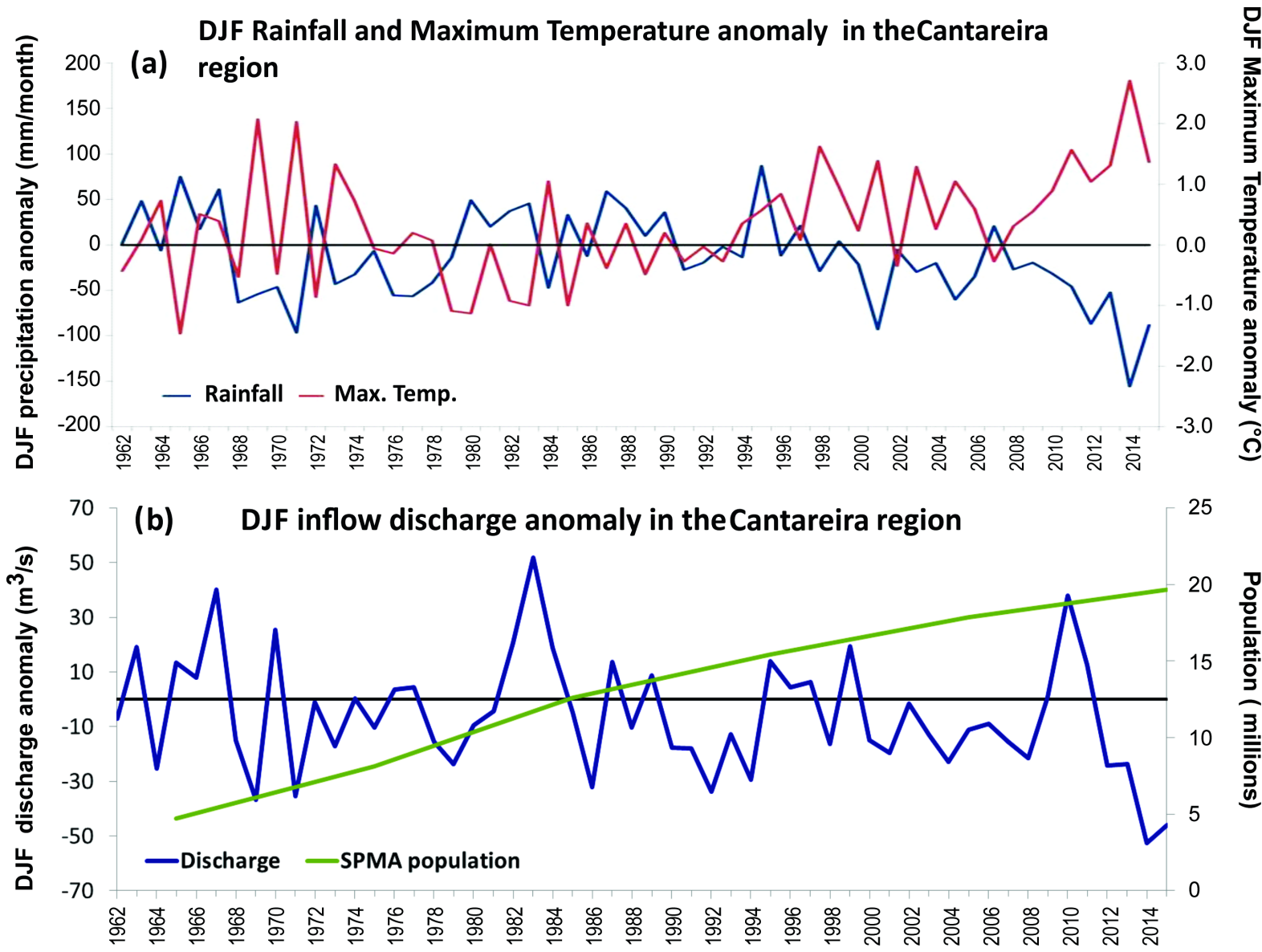

Figure 2. Time series of (a) rainfall ( $\mathrm{mm}$ month $^{-1}$ ) and maximum air temperature $\left({ }^{\circ} \mathrm{C}\right)$ anomalies over the Cantareira reservoir system region from 1961 to 2015; (b) inflow discharge anomalies ( $\mathrm{m}^{3} / \mathrm{s}$ ) at the Cantareira reservoir system during 1961 to 2015 (in blue) and population (in millions) in the SPMA (in green). Anomalies are relative to the 1961-90 long term mean and for the austral summer season December-January-February. Data comes from SABESP (discharge) and from the state of Sao Paulo Municipality (population).

1-15 January 2014

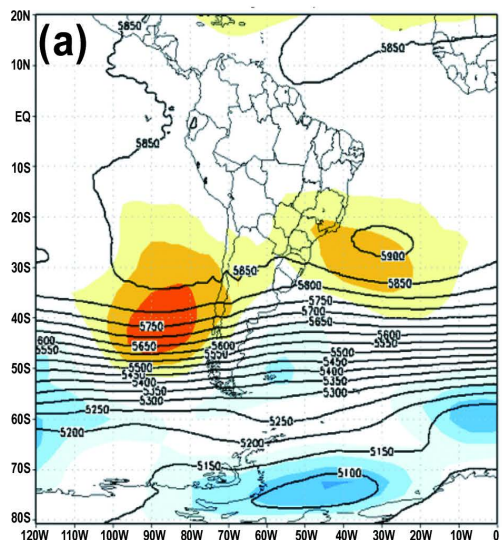

16-31 January 2014

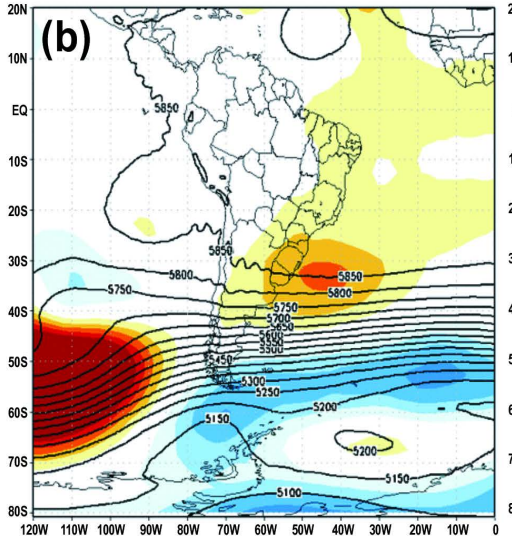

1-15 February 2014

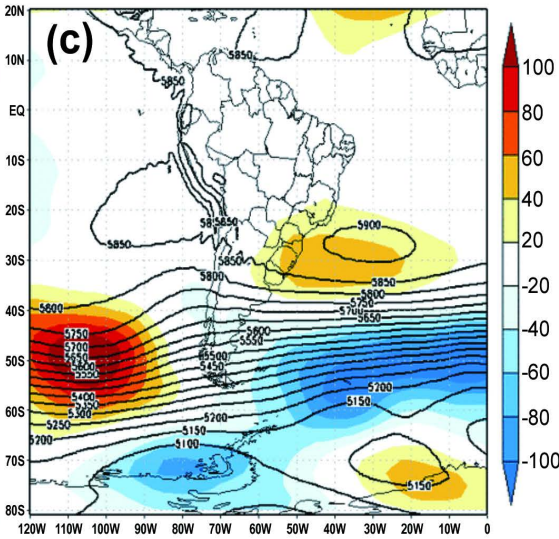

Figure 3. 500-hPa geopotential height (contours) and anomalies (color) during (left) 1-15 January 2014, (center) 16-31 Jan 2014, and (right) 1-15 Feb 2014. All units are in meters.

in the southwestern Amazon over the Madeira and Beni river basins in the western Brazilian Amazon and Bolivia [11]. 
Usually, broad barotropic warm core quasi-stationary anticyclones that extend almost throughout the entire troposphere are classified as "blocking highs". Blocking systems are related to low level zonal circulation and jet stream splitting that cause the suppression of baroclinic transient activity and persistent rainfall/drought or cold/warm surges depending on its relative position. Blocking anticyclones typically occur at middle latitudes, especially over the Pacific Ocean [12] and last around 7 - 8 days, with cases longer than 15 days being extremely rare [13]. Although strong sea surface temperature variability during 2013 and 2014 has been related to strong temperature anomalies in North America [14], blocking over the subtropical Atlantic Ocean is rather insensitive to sea surface anomalies in the Pacific Ocean. However, [5] found that the South Atlantic blocking highs are traced diagnostically to a warm tropical West Pacific SST. Persistent blocking and hence clear skies induced strong warm anomalies over the Atlantic Ocean that lasted until May 2015 (www.cptec.inpe.br/clima).

According to our own calculations, the blocking high lasted around 45 days between January and February 2014. The study by [6] for the summer of 2014 in the South Atlantic indicated that during this long-lasting blocking episode there was a sequence of 30 consecutive dry days. A similar mechanism was observed during drought events in other regions of the world. In North America, [15] and [16] demonstrated that extreme precipitation deficits and drought over California during early 2013 were due to the blocking by persistent high anomalies over the northeast Pacific.

\subsection{Regional Warming and Drought in 2014 and 2015}

Observed changes in regional temperature and precipitation can often be physically related to one another; dry conditions favor more sunshine and less evaporative cooling, and drought is a result of low precipitation and/or high temperature that determine soil moisture deficiency. Higher regional temperatures contribute to the severity of droughts by means of a drier soil, leading to a warmer/drier and expanded planetary boundary layer as shown by the positive $500 \mathrm{hPa}$ anomalies detected in southeastern Brazil during DJF 2013/14 by [9], and thus reducing thermodynamic instability and inhibiting convective precipitation [17]. Figure 2(a) shows that regional maximum temperatures over the Cantareira region have been increasing since 1961, consistent with rainfall reduction.

Figure 4 shows that during 1961-2015 the number of drought episodes—both short and long term-has increased as compared to 1961-2000. While dry episodes lasted up to 4 months in 1961-2000, dry periods in the 6 - 12 month time scale were more frequent in 1961-2015. This suggests that dry periods were longer in the recent decade. In the same vein, Figure 5 shows that the Cantareira region experienced the most severe drought during the austral summer of 2014, and that this year corresponds to the warmest year in the region since 1961 $\left(94.5 \mathrm{~mm}, 31.4^{\circ} \mathrm{C}\right)$. Other drought years, such as $1971\left(153.4 \mathrm{~mm}, 30.7^{\circ} \mathrm{C}\right), 2001\left(153.4 \mathrm{~mm}, 30.7^{\circ} \mathrm{C}\right)$ and 2015 $\left(160.0 \mathrm{~mm}, 30.1^{\circ} \mathrm{C}\right)$ were also among the six warmest years during that period. As a reference, the mean summer rainfall (1961-1990) is $249.9 \mathrm{~mm}$, and mean maximum temperature is $28.7^{\circ} \mathrm{C}$.

From Figure 5, warm summers as in 2013/14 are associated with low precipitation. The correlation between DJF rainfall and maximum temperature over the Cantareira region reached -0.69 , significant at the 0.01 level. The summer of 2013/14 was the driest and warmest since 1961, with record maximum temperatures, and that together with an increase in water demand for a growing population generated the water crisis that has affected the SPMA since the austral summer of 2014. From Figure 4 and Figure 5, it is observed that the long-term warming in the region has contributed to an increased risk of severe drought and a deepening of the impacts of the water crisis, as seen in 2014 and 2015, but this warming alone cannot explain the circulation features leading to the rainfall deficiency. The water crisis can be explained by a combination of higher temperatures that determined a larger water use for an increasing population, but we do not present any evidence that such atmospheric conditions have become more prevalent as a result of anthropogenic climate change. What we can say is that the impacts of this drought and the resulting water crisis have in fact been consequences of increased water use in a warmer summer, when discharges into the Cantareira system were very low. This is confirmed by [18] who show that anthropogenic climate change is not found to be a major influence on the drought of 2013/14 and 2014/15, whereas increasing population and water consumption increased vulnerability.

\section{Hydrological Context and Impacts of the Water Crisis}

The current drought seems to have started in 2011, as suggested by [10]. The mean annual tributary discharge into the Cantareira system is $44.1 \mathrm{~m}^{3} / \mathrm{s}(1930-2013)$ Figure 6. In 1953 it was only $24.6 \mathrm{~m}^{3} / \mathrm{s}$ and in 2014 it 


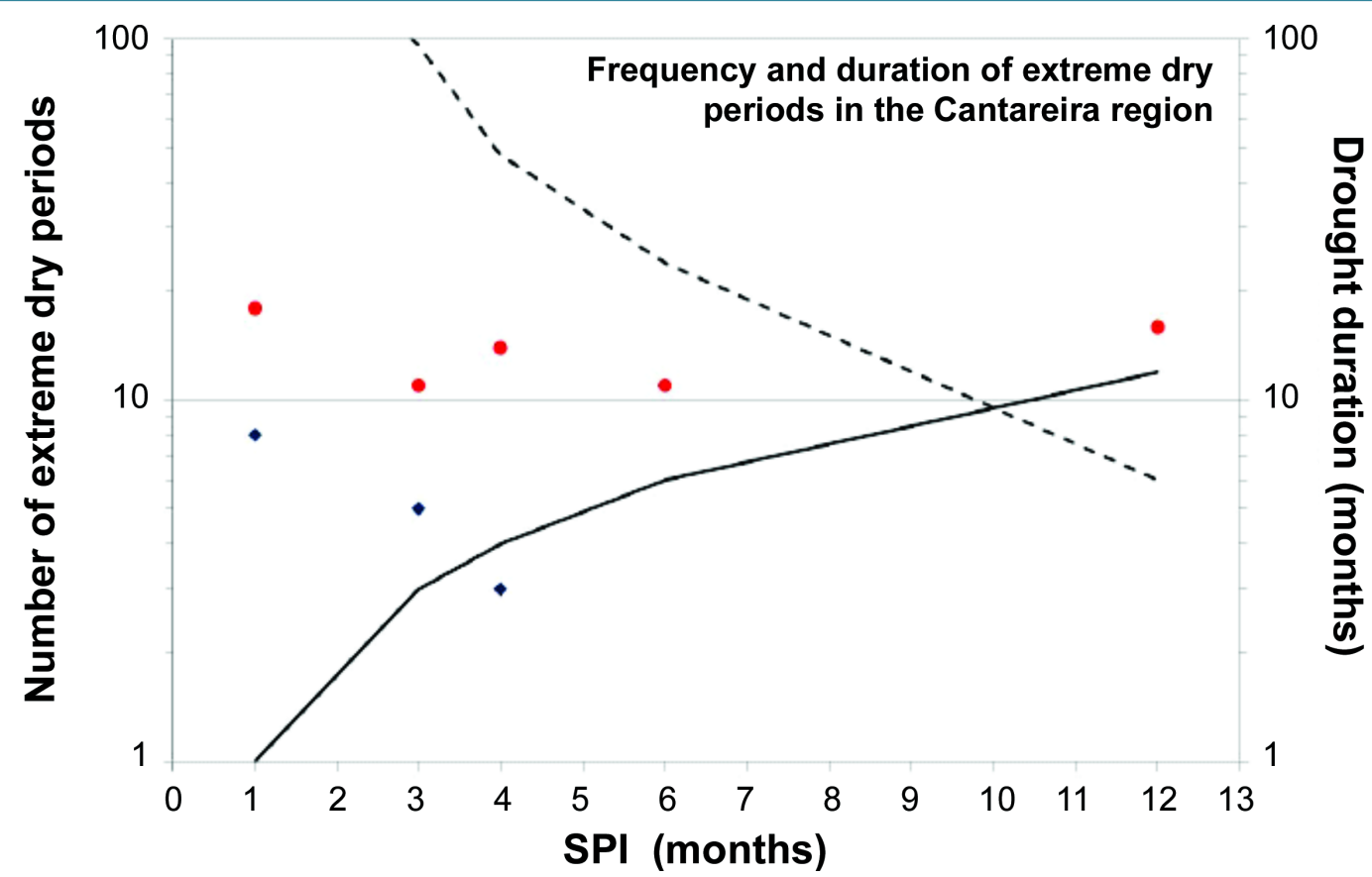

Figure 4. Frequency and duration of droughts as a function of time period for the Cantareira reservoir region. The blue diamonds represent the Standardized Precipitation Index (SPI) based on 40 years (1961-2000) and red circles the SPI based on 55 years (1961-2015). The added lines suggest schematically the expected relationships between time scale vs. number of droughts (dashed) and vs. duration of droughts (solid).

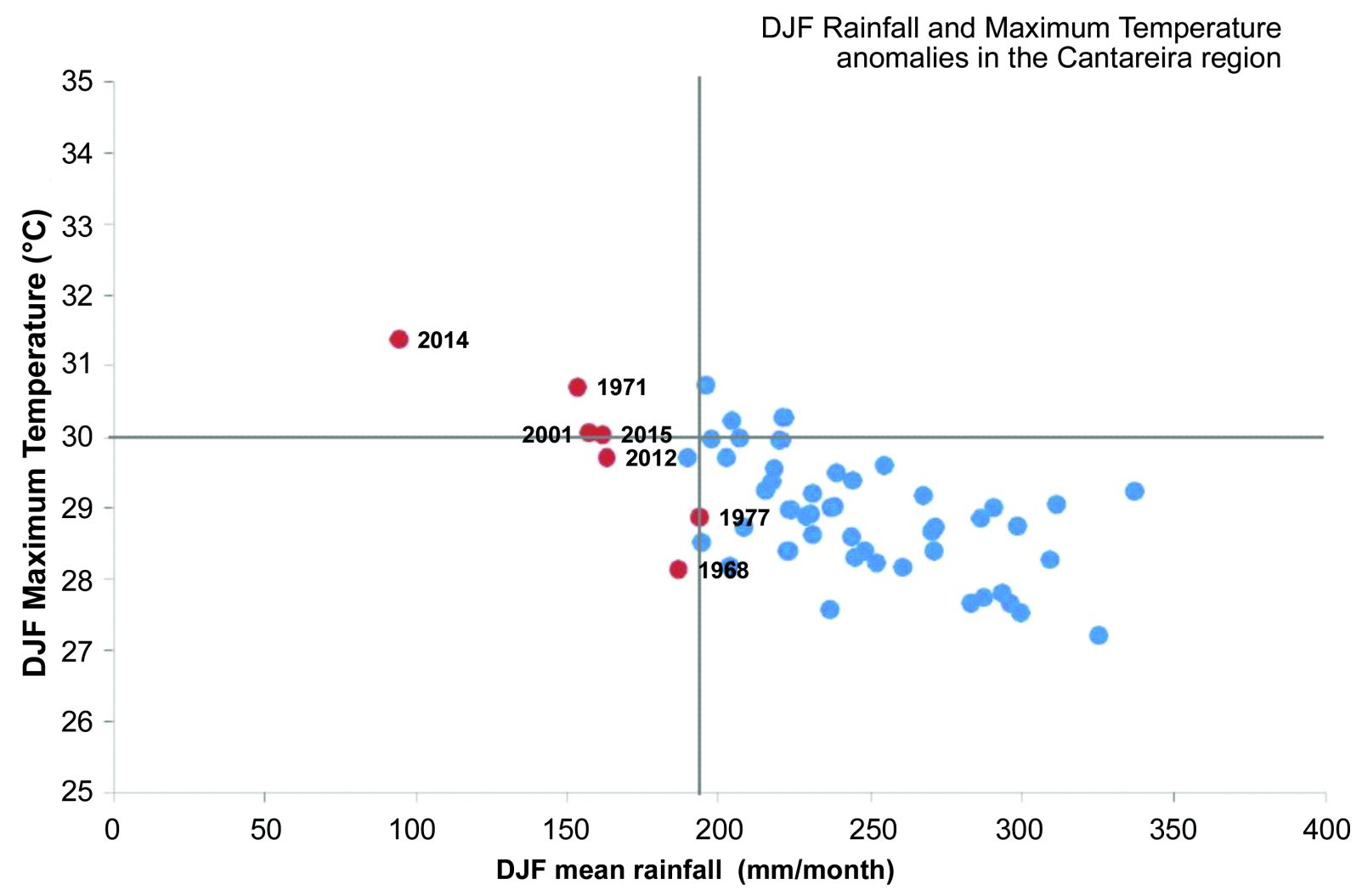

Figure 5. Scatter plot showing maximum temperature and precipitation during the austral summer rainy season DJF over Cantareira region in southeast Brazil. The driest years are shown with red dots. The threshold levels for temperature and precipitation, corresponding to the 0.85 and 0.15 percentile, respectively, are shown with grey lines. 


\section{Cantareira Water Supply System}

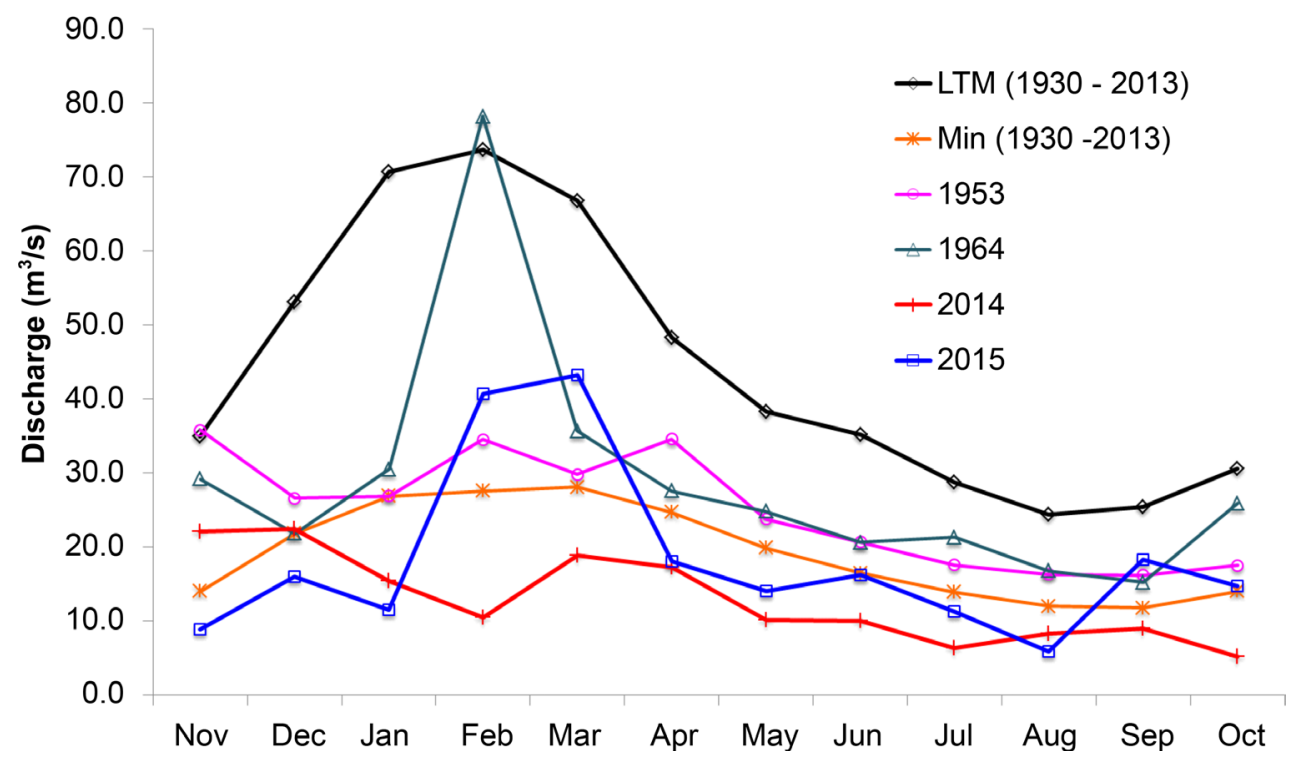

Figure 6. Annual cycle of the inflow discharge into the Cantareira reservoir system $\left(\mathrm{m}^{3} / \mathrm{sec}\right)$. Black line shows the 1930 2013 long term mean, and orange line shows the mean minimum discharge during 1930-2013. Some dry years are shown: pink line shows the year 1953; green line shows 1964; red line shows 2014; and blue line shows 2015. We consider the hydrological year November-October.

reached its lowest at $11.3 \mathrm{~m}^{3} / \mathrm{s}$. Mean discharge in the summer (Nov-Mar) of 2014 was $17.9 \mathrm{~m} / \mathrm{s}$ and in 2015 it was $24.0 \mathrm{~m}^{3} / \mathrm{s}$, far below the average summer discharge, $59.8 \mathrm{~m}^{3} / \mathrm{s}(70.0 \%$ and $60 \%$, respectively), for the period 1930-2013. The 1953/54 rainfall deficit prompted construction of the Cantareira Reservoir system [19]. After this, longer-term planning by regional governments has fallen short, and many residents are already enduring sporadic water cutoffs, some lasting for many days. The Cantareira reservoir system reached critical conditions in early 2015. Storage levels were only 5\% of its 1.3 billion $\mathrm{m}^{3}$ capacity in January 2015 and $15 \%$ at the end of the rainy season in March 2015.

According to the state of São Paulo official site (http://www.emplasa.sp.gov.br) the urban area of the SPMA increased from $200 \mathrm{~km}^{2}$ in 1930 to $2407 \mathrm{~km}^{2}$ in 2002, a factor of 12 in seven decades, and the population went from less than 2 million inhabitants in 1940 to almost 20 million by 2014 (Figure 2(b)). In 1980, when the Cantareira water supply system became fully operational, the population was 12.6 million. Lower rainfall decreased water availability, and higher temperatures led to increased evapotranspiration water use-in agriculture, industry, and people's homes. The city's rapid development over recent decades had increased its vulnerability: population growth increased water demand; forests and wetlands that had historically soaked up rainwater and released it slowly into reservoirs were destroyed; and poor-quality infrastructure continued to leak some $30 \%$ - $40 \%$ of the system's water. Since 2014, SABESP has already reduced pressure in the pipes to force conservation and to reduce losses from the leaks, a strategy that has cut off running water to millions of customers for hours and even days, depending on where people live.

The drought's pervasive impacts are enormous, hobbling industry and agriculture, hampering operations at hospitals, and activities at schools. The most direct impact, obviously, has been a lack of water that has hampered the functioning of schools, hospitals and businesses. Agriculture has suffered: the price of products such as tomatoes and lettuce increased by around $30 \%$ at the height of the drought; other affected crops included sugar cane, oranges and beans. As a consequence, the sugar cane harvest for 2014/15 was about 5\% lower than in previous years coffee and fruits should show a reduction of between 15\% - 40\% in Sao Paulo State, and soybean production was about 55 million MT lower than in previous years [20]. Parts of the city relied on water-trucks for their supply during 2014 and most of 2015.

The current water crisis and the water restrictions affect Brazilian agribusiness, and there are projections of losses of about R $\$ 20$ billion (about US \$5 billion) in the agricultural sector for 2014 [20]-[22]. This represents a reduction of about 6.7\% as compared to the income from the sector of $\mathrm{R} \$ 300$ billion in 2013. Meanwhile, the 
number of forest fires in the region increased by 150\% from 2013 to 2014. Electricity generation has also been affected. More than $70 \%$ of Brazil's electricity supply comes from hydroelectric power, and around $70 \%$ of this is generated in the São Paulo region. By the end of 2014, the reservoirs supplying this power generation were almost dry. As a result, energy prices were predicted to increase by $20 \%-25 \%$ in 2015 . The effects of the water shortage, including water rationing, increased water bills, and other inconveniences have even led to protests and social unrest in some parts of the city [20].

According to Munich-Re [21], the absence of rain during 2014 in southeast Brazil had a severe effect on the agricultural sector, and the overall loss from this drought so far has been estimated at US \$5 billion, making it the $5^{\text {th }}$ worst natural disaster in economical terms worldwide in 2014. Swiss-Re estimated the damages in 2014 to be on the order of US \$3 billion [23]. Moreover, origins of the current water crisis go beyond the rainfall deficiency, to include an array of interconnected factors: the city's surging population growth in the $20^{\text {th }}$ century; a chronically leaky system that spills vast amounts of water before it can reach homes; the destruction of surrounding forests and wetlands that have historically soaked up rain and released it slowly into reservoirs; and the increase in water use for the population due to warmer summers.

\section{Conclusions}

The climatic factors influencing the drought in Sao Paulo are related to changes in atmospheric circulation that affect large-scale weather patterns over the adjacent Pacific and Atlantic sectors. Over the southeastern South America-South Atlantic sector, atmospheric conditions are such that they block the passage of cold fronts from the south and moisture from the Amazon region, leaving dry conditions over southeast Brazil with wet conditions observed over western Amazonia and southern Brazil during austral summer. These blocking conditions persisted for 45 days during the summer of 2014, something not seen since 1961.

The complexity and severity of the observed drought impacts coupled with regional warming have increased the amplitude of the water crisis in the SPMA. The drought during the summer of 2013/14 generated the worst water crisis in Sao Paulo since 1961. The fact that the summer season of 2014 was the warmest in 55 years shows that the water crises during 2014 and 2015 are a relevant example of increased vulnerability to climate change due to human-caused increases in temperature. While we do not find an increased probability of drought due to human-induced climate change or due to deforestation in the Amazon region [24], there is evidence that there is an increased risk of droughts of the intensity of that observed in 2014 due to the increased warming seen in the region since 1961.

After the droughts of 1953, 2001 and now in 2014 it is clear that the SPMA is vulnerable to water scarcity. The socio-economic-political situation, including larger water demand for a growing population may have aggravated the situation, generating an acute water crisis that is in its second year. As such, resilience depends on numerous factors; but how populations will cope with disasters of various magnitudes is largely dictated by political actions, socioeconomic development and education. Populations and governments in the SPMA and in Brazil need to raise awareness about limited freshwater resources so the present sets the right stage for a sustainable future. Resilience depends on numerous factors among them to increase water availability for a growing population by updating the water transportation system to reduce leaking, and perhaps invest in larger water storage systems to take advantage from other rivers in the region, such as the Paraiba do Sul. However, how populations will cope with disasters of various magnitudes is largely dictated by political actions, socioeconomic development and education.

Ongoing studies assess the link between climate change and human induced warming and persistent South Atlantic blocking highs over southeastern Brazil, and this understanding will be crucial in characterizing the future risk of severe drought.

\section{Acknowledgements}

C.A.N and J.A.M acknowledge the support of the Brazilian Research Council CNPq, FAPESP-Belmont Grant 2012/51876-0, and the Climate Change Risks-Limits to Adaptation/UK Embassy in Brazil. We thank INMET, INPE, SABESP and CEMADEN for providing climatic and hydrological data for this study.

\section{References}

[1] DAEE (2013) Macrometrópole. Sumario Executivo-Plano Diretor de Aproveitamento de Recursos Hídricos para a 
Macrometrópole Paulista. Departamento de Aguas e Energia Elétrica (DAEE). Secretaria de Planejamento e Desenvolvimento Regional, Secretaria do Meio Ambiente, Secretaria de Saneamento e Recursos Hídricos. Governo do Estado de São Paulo, São Paulo, Brasil, 44 p. [Macrometropole: Executive Summary-Director Plan for Utilization of Water Resources in the Megacity of Sao Paulo. Department of Waterand Electric Energy (DAEE). Secretary for Planning and Regional Development, Secretary of Environment, Secretary of Sanitation and Water Resources. Government of the State of Sao Paulo.]

[2] Cavalcanti, I.F.A. and Kouksy, V.E. (2001) Drought in Brazil during Summer and Fall of 2001 and Associated Circulation Features. Climanalise, 1, 1-10. http://climanalise.cptec.inpe.br/ rclimanl/revista/pdf/criseing.pdf

[3] Coelho, C.S., Cardoso, D.F. and Firpo, M.F. (2015) Precipitation Diagnostics of an Exceptionally Dry Event in Sao Paulo, Brazil. Theoretical and Applied Climatology, 1-16. http://dx.doi.org/10.1007/s00704-015-1540-9

[4] Coelho, C.S., Oliveira, C., Ambrizzi, T., Reboita, M., Carpenedo, C., Campos, J., Tomaziello, A., Pampuch, L., Custodio, M.S., Dutra, L., Da Rocha, R. and Rehbein, A. (2015) The 2014 Southeast Brazil Austral Summer Drought: Regional Scale Mechanisms and Teleconnections. Climate Dynamics, 1-16. http://dx.doi.org/10.1007/s00382-015-2800-1

[5] Seth, A.K., Fernandes, K. and Camargo, S. (2015) Two Summers of Sao Paulo Drought: Origins in the Western Tropical Pacific. Geophysical Research Letters, in Press. http://dx.doi.org/10.1002/2015GL066314

[6] Silva, W.L., Nascimento, M.A. and Menezes, W.F. (2015) Atmospheric Blocking in the South Atlantic during the Summer 2014: A Synoptic Analysis of the Phenomenon. Atmospheric and Climate Sciences, 5, 386-393. http://dx.doi.org/10.4236/acs.2015.54030

[7] Rozante, J.R., Moreira, D.S., de Goncalves, L.G.G. and Vila, D.A. (2010) Combining TRMM and Surface Observations of Precipitation: Technique and Validation over South America. Weather and Forecasting, 25, 885-894. http://dx.doi.org/10.1175/2010WAF2222325.1

[8] Obregón, G.O., Marengo, J.A. and Nobre, C.A. (2014) Rainfall and Climate Variability: Long-Term Trends in the Metropolitan Area of São Paulo in the 20th Century. Climate Research, 61, 93-107. http://dx.doi.org/10.3354/cr01241

[9] Marengo, J.A., Alves, L.M., Espinoza, J.C. and Ronchail, J. (2014) Tropical South America East of the Andes [in "State of the Climate in 2014"]. Bulletin of the American Meteorological Society, 95, S170-S171.

[10] Getirana, A. (2015) Extreme Water Deficit in Brazil Detected from Space. Journal of Hydrometeorology, 17, $591-599$. http://dx.doi.org/10.1175/JHM-D-15-0096.1

[11] Espinoza, J.C., Marengo, J.A., Ronchail, J., Molina, J., Noriega, L. and Guyot, J.L. (2014) The Extreme 2014 Flood in South-Western Amazon Basin: The Role of Tropical-Subtropical South Atlantic SST Gradient. Environmental Research Letters, 9, Article ID: 124007. http://dx.doi.org/10.1088/1748-9326/9/12/124007

[12] Oliveira, F.N.M. (2011) A Climatology of Southern Hemisphere Blockings: Observations, Simulations of the 20th Century and Future Climate Change Scenarios. PhD Dissertation, Institute of Astronomy, Geophysics and Atmospheric Sciences, University of Sao Paulo, Brazil, 158 p. (In Portuguese)

[13] Oliveira, F.N.M., Carvalho, L.M.V. and Ambrizzi, T. (2014) A New Climatology for Southern Hemisphere Blockings in the Winter and the Combined Effect of ENSO and SAM Phases. International Journal of Climatology, 34, 16761692. http://dx.doi.org/10.1002/joc.3795

[14] Hartmann, D.L. (2015) Pacific Sea Surface Temperature and the Winter of 2014. Geophysical Research Letters, 42, 1894-1902. http://dx.doi.org/10.1002/2015GL063083

[15] Wang, H. and Schubert, S. (2014) Causes of the Extreme Dry Conditions over California during Early 2013 [in "Explaining Extreme Events of 2013 from a Climate Perspective”]. Bulletin of the American Meteorological Society, 95, S7-S11.

[16] Diffenbaugh, N.S., Swain, D.L. and Touma, D. (2015) Anthropogenic Warming Has Increased Drought Risk in California. Proceedings of the National Academy of Sciences of the United States of America, 112, 3931-3936. http://dx.doi.org/10.1073/pnas.1422385112

[17] Collini, E., Berbery, E., Barros, V. and Pyle, M. (2008) How Does Soil Moisture Influence the Early Stages of the South American Monsoon? Journal of Climate, 21, 195-213. http://dx.doi.org/10.1175/2007JCLI1846.1

[18] Otto, F.E.L., Coelho, C.A.S., King, A., Coughlan de Perez, E., Wada, Y., van Oldenborgh, G.J., Haarsma, R., Haustein, K., Uhe, P., van Aalst, M., Aravequia, J.A., Almeida, M.W. and Cullen, H. (2015) Factors Other than Climate Change, Main Drivers of 2014/15 Water Shortage in Southeast Brazil [in "Explaining Extremes of 2014 from a Climate Perspective”]. Bulletin of the American Meteorological Society, 96, S35-S40. http://dx.doi.org/10.1175/BAMS-EEE_2014_ch8.1

[19] Porto, R.L., Porto, M.F.A. and Palermo, M. (2014) A ressurreição do volume morto do Sistema Cantareira na Quaresma [The Resurrection of the Dead Volume in the Cantareira System during the Lent]. Revista DAE, 62, 18-25. http://dx.doi.org/10.4322/dae.2014.131

[20] UNICA (2015) Centre for Food Storage and Market Distribution of the State of São Paulo (CEAGESP), the Brazilian 
Citrus Association, the Cereal Stock Market of São Paulo and the Brazilian Union of Sugar Cane Producers. http://www.unica.com.br/

[21] Munich Re (2015) Natural Catastrophes 2014. Analyses, Assessments, Positions. TOPICS-GEO 2014, Munich, 67 p.

[22] King, D., Schrag, D., Zhou, D., Ye, Q. and Ghosh, A. (2015) Climate Change: A Risk Assessment-Risk Assessment Part 3: Systemic Risks. Hynard, J. and Rodger, T., Eds., Centre for Social Science and Policy, London, 110-111.

[23] Swiss-Re (2015) Natural catástrofes and Man-Made Disasters in 2014: Convective and Winter Storms Generate Most Losses. Swiss Re Ltd-Economic Research and Consulting, Zurich, Swiss Re-Sigma No. 2/2015, 52 p.

[24] Marengo, J.A. and Alves, L.M. (2015) Crise Hídrica em São Paulo em 2014: Seca e Desmatamento [Water Crisis in Sao Paulo in 2014: Drought and Deforestation]. GEOUSP, USP-Sao Paulo. (In Press) 